The Faces of Buddbism in America 



\title{
The Faces of
} Buddbism

in America

\author{
EDITED BY CHARLES S. PREBISH
}

AND KENNETH K. TANAKA

University of California Press

Berkeley Los Angeles London 
University of California Press

Berkeley and Los Angeles, California

University of California Press, Ltd.

London, England

(C) 1998 by

The Regents of the University of California

Part of chapter 2 appeared in much abbreviated form as "The

Western Pure Land: Shin Buddhism in America," Tricycle 4, no. 4 (summer 1995).

Library of Congress Cataloging-in-Publication Data

The faces of Buddhism in America / Charles S. Prebish and Kenneth K. Tanaka, editors.

p. $\quad \mathrm{cm}$.

Includes bibliographical references and index.

ISBN 0-520-20460-3 (alk. paper). — ISBN 0-520-2 1301-7

(pbk. : alk. paper)

1. Buddhism-United States. I. Prebish, Charles S.

II. Tanaka, Kenneth Ken'ichi.

BQ746.F35 $199^{8}$

294.3'0973-dc2 1

Printed in the United States of America

987654321

The paper used in this publication is both acid-free and totally chlorine-free (TCF). It meets the minimum requirements of American Standard for Information Sciences-Permanence of Paper for Printed Library Materials, ANSI Z39-48-1984. 